論文

대기압 화염 플라즈마 처리가 강판의 표면 및 고무와의 접착특성에 미치는 영향

류상렬*, 이동주 ${ }^{* *+}$

\title{
Effect of Atmospheric Pressure Flame Plasma Treatment on Surface and Adhesive Bonding Properties between Steel Plate and Rubber
}

\author{
Sang Ryeoul Ryu*, Dong Joo Lee ${ }^{* *+}$
}

\begin{abstract}
To increase the adhesive strength of acrylonitrile butadiene rubber(NBR) and steel plate, the atmospheric pressure flame plasma(APFP) treatment device is applied. The effect of various conditions(processing velocity and distance) is experimentally investigated to ascertain the optimum conditions to yield the best adhesive properties. It is found that the optimum distance between burner port and steel plate is $40 \mathrm{~mm}$ and the optimum processing velocity is $50 \mathrm{~m} / \mathrm{min}$ at given condition. When the surface is coated twice with the bonding agent, the adhesion strength of APFP treated steel plate is increased to about 20.5\%. It suggests that the surface modification of steel by flame plasma treatment at atmospheric pressure is a proper and applicable method to improve the adhesion strength between steel and rubber.
\end{abstract}

\section{초 록}

$\mathrm{NBR}$ 과 강판의 접착특성을 향상시키기 위해 대기압 화염 플라즈마(APFP) 처리 장치가 사용되었다. 가장 우수한 접착특성 을 나타내는 최적 조건을 찾기 위해 다양한 처리 조건(처리속도, 거리)에 따른 효과에 대한 실험적 연구를 하였다. 주어진 조 건에서 버너 포트와 강판의 최적 거리는 $40 \mathrm{~mm}$, 버너 포트의 최적 처리속도는 $50 \mathrm{~m} / \mathrm{min}$ 였다. APFP 처리 후 접착제를 두 번 도포한 강판의 접착강도는 접착제만 도포한 경우보다 $20.5 \%$ 증가하였다. 본 연구를 통해서 대기압 화염 플라즈마 처리에 의 한 강판의 표면개질이 고무와 강의 접착강도를 증가시키는 적절하면서도 응용이 가능한 방법임을 확인하였다.

Key Words : 대기압 화염 플라즈마(atmospheric pressure flame plasma), 처리속도(processing velocity), 표면거칠기(surface roughness), 접촉각(contact angle), 접착강도(adhesion strength)

\section{1. 서 론}

고분자 복합재료의 기계적 물성 향상에 대한 연구는 표면코 팅 및 커플링제 처리를 기본으로 열 표면처리, 화학적 표면처 리, 전기화학적 표면처리, 플라즈마 표면처리 등과 같은 방법에 대해 많은 연구가 이루어져 왔다[1-6]. 최근 몇 년 동안 $\mathrm{DBD}$ (dielectric barrier discharge)[7], 플라즈마 제트, 마이크로파 플라즈마 토치 등과 같은 대기압 플라즈마(APP, atmospheric pressure plasma) 방식들이 개발되었다. 이러한 시스템들은 표면 세정 및 윤활 방지, 표면 개질, 박막 증착 등과 같은 다양한 응 용을 위해 광범위하게 연구되고 있다[8]. 대기압 플라즈마를 이 용한 접착 특성에 관한 연구는, $\mathrm{Han}[7]$ 등은 $\mathrm{DBD}$ 방식의 플라 즈마를 이용한 $\mathrm{PET}$-필름과 강의 접착 특성향상에 관한 연구를 하였다. 이[9] 등은 대기압 $\mathrm{Ar} / O_{2}$ 플라즈마를 이용 자동차용 냉연강판의 표면 특성 평가 및 접착력 향상에 관한 연구를 하 였으며, 이[10] 등은 알루미늄에 DC 플라즈마 처리를 통한 전 
단강도 및 T-peel 강도가 크게 증가함을 보였다.

본 논문에서는 지금까지 많이 적용되지 않은 대기압 플라즈 마의 일종인 대기압 화염 플라즈마(APFP, atmospheric pressure flame plasma)를 사용한다. 대기압 화염 플라즈마는 글로우 방 전(glow discharge) 방식의 일종으로 열 융합 방식에 의해 열원 가스(LPG 혹은 LNG)를 대기압 하에서 완전 연소시켜 플라즈 마 구역을 형성하게 되고, 표면의 에너지(전자 밀도 $10^{13} \sim 10^{16}$ ) 를 향상시키는 방법이다. 대기압 화염 플라즈마 처리의 특징은 높은 수준의 균일한 처리가 가능하며 표면 잔해의 연마 및 제 거, 처리속도가 매우 빠르고, 특별한 장치가 불필요해 경제적이 며 사용이 간편하다. 단점으로는 처리시간에 따라 열의 영향을 받는 것이다. 이러한 대기압 화염 플라즈마 처리를 이용한 물 성 향상에 대한 연구는 아직 보고되고 있지 않으며, 이에 대한 체계적인 연구가 필요한 실정이다.

본 연구에서는 강판의 표면에 대기압 화염 플라즈마 처리를 통한 강판의 표면 특성 및 강판과 고무의 접착 특성에 대해 연구하고자 한다. 자동차를 비롯한 여러 산업 분야 사용되는 고무 부품 중 엔진 마운트, 스토퍼(stopper), 부싱, 패킹, 오일씰 등과 같이 고무와 보강재가 결합된 형태가 많은 부분을 차 지한다. 이런 형태의 부품에서 가장 중요한 성능은 내구성이며 이를 위해서는 고무와 보강재 사이의 접착 특성이 매우 중요 하다고 할 수 있다.

\section{2. 실험 재료 및 방법}

\section{1 실험재료}

실험에 사용된 고무는 Table 1 과와 같이 카본블랙과 가류제 등이 포함된 합성고무의 일종인 NBR(acrylonitrile butadiene rubber)이고 인장강도와 신장률, 그리고 경도는 $12.26 \mathrm{MPa}$, $520 \%, 51 \mathrm{Hs}(\mathrm{A})$ 이었다. 또한 실험에 사용된 피착제인 강은 일 반열간압연강판 $(\mathrm{SPH} 1)$ 으로 크기는 $60 \times 25.4 \times 2.5 \mathrm{t}$ 이었다.

피착제인 강판의 접착 처리는 실내(온도: $25^{\circ} \mathrm{C}$, 습도: $50 \%$ ) 에서 다음과 같은 순서로 실시하였다. (1) 표면을 사포 $\# 800 \rightarrow$ $\# 1000 \rightarrow \# 1500 \rightarrow \# 2000)$ 를 이용하여 연마하고, 압축 공기를 이 용하여 청소, (2) TCE(trichloroethylene) 용액을 이용하여 세정 및 탈지, (3) 실온에서 30 분 건조, (4) 화염 플라즈마 처리, (5) 접착제 처리 후, 실온에서 30 분 건조. 접착제는 한국 $\mathrm{LORD}$ 사 의 Chemlok $\mathrm{AB}$ 를 사용하였다. 피착제의 표면에 대한 접착제 처리는 크게 2 가지로 구분하였다. “C”는 캠록을 1 회 처리한 것이고, “CC"은 “C” 처리를 반복한 것을 의미한다. 또한 피착 제의 플라즈마 처리한 경우(“PC”, "PCC”)와 처리하지 않은 경우(“C”, “CC”)로 구분하여 비교하였으며, 플라즈마 처리 조 건을 변화시키면서 최적의 물성을 나타내는 처리 조건에 대해 서도 검토하였다.

접착 시험용 시험편 제작을 위해 혼합된 고무와 강판을 금 형에 넣고 80 톤 압축프레스를 이용하여 압축성형 하였다. 성형
중의 압력은 $14 \mathrm{MPa}$, 온도는 $160^{\circ} \mathrm{C}$ 그리고 시간은 6 분이었다.

Table 1 Fonmulation of nubber matrix

\begin{tabular}{ccc}
\hline \hline & Ingredients & phr \\
\hline Polymer & DN-402 & 100.0 \\
\hline Zinc oxide & $\leftarrow$ & 5.0 \\
\hline Stearic acid & $\leftarrow$ & 1.0 \\
\hline Carbon black & N774(SRF) & 45.0 \\
\hline Filler & Clay(BKS) & 25.0 \\
\hline Processing oil & Dioctyl Phthalate & 5.0 \\
\hline \multirow{2}{*}{ Antioxidants } & Kumanox 3C & 3.0 \\
& Kumanox RD & 1.5 \\
& Sunplax 682 & 2.0 \\
\hline \multirow{2}{*}{ Accelerators } & Oricell TT & 1.2 \\
& Vanax NS & 2.0 \\
\hline Curing agent & Sulfur & 0.8 \\
\hline \hline & Sum. & 191.5 \\
\hline \hline
\end{tabular}

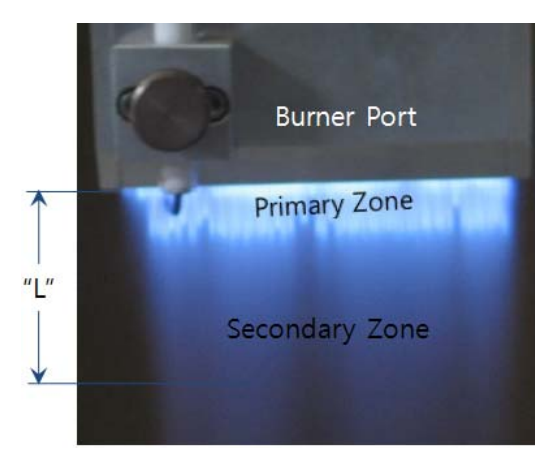

Fig. 1 A flame plasma and distance(“ $L$ ”) from the bumer port.

\section{2 화염 플라즈마 처리}

화염 플라즈마 처리는 API(주)의 Super Flame ${ }^{\circledR}$ Center를 사용하였으며, 연소가스의 연소반응과 피착제 표면처리 조건 은 다음과 같이 하였다.

$$
\mathrm{C}_{3} \mathrm{H}_{8}+\mathrm{O}_{2}=\mathrm{CO}_{2}+\mathrm{H}_{2} \mathrm{O}+\text { Heat }+ \text { Flame Plasma }
$$

$C_{3} H_{8}(4 \ell / \mathrm{min})$ 와 압축공기(100 $\left.\ell / \mathrm{min}\right)$ 의 혼합 비율은 $1: 25$ 로 유지하고, 처리 횟수는 1 회 왕복 처리 후 5 분을 유지하고 1 회 반복 처리한다. 버너 포트(burner port)와 직물의 일정거리 유지 를 위해 지지판을 설치하고, 지지판 위에 피착제를 놓고 플라즈 마 처리한다. 버너 포트는 직사각형으로 크기는 $85 \times 13$ 이고, Fig. 1 과 같이 버너 포트로부터 피착제까지의 거리(“L”)를 25,40 , $55,70(\mathrm{~mm})$ 로 구분하였다. 버너 포트의 이동속도(플라즈마 처리 속도) 또한 중요한 변수가 되며 $20,35,50,65(\mathrm{~m} / \mathrm{min})$ 로 구분 하여 화염 플라즈마의 영향을 검토였다. 또한 화염 플라즈마 처 리 후의 표면 특성을 검토하기 위하여 플라즈마 처리된 표면에 대해 광학 현미경 사진, $\mathrm{SEM}$ 사진, 표면 거칠기 그리고 접촉각 측정 등을 실시하여 비교하였다. 


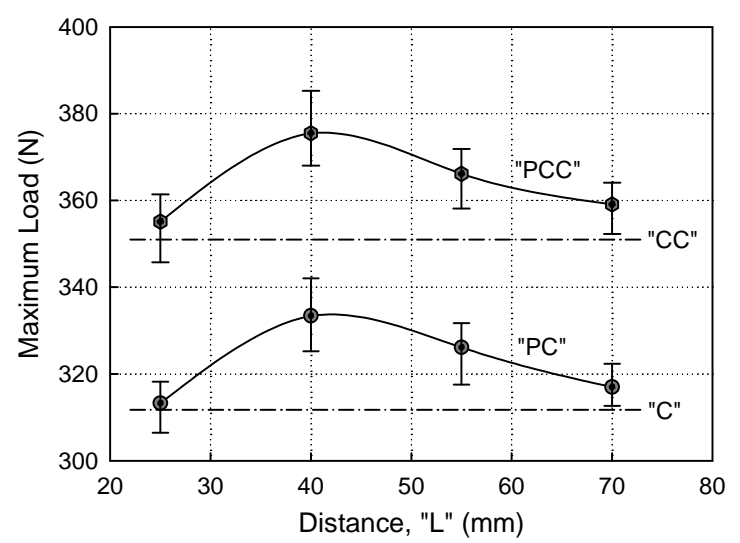

Fig. 2 Effects of flame plasma length between bumer port and steel plate on the maximmm load.

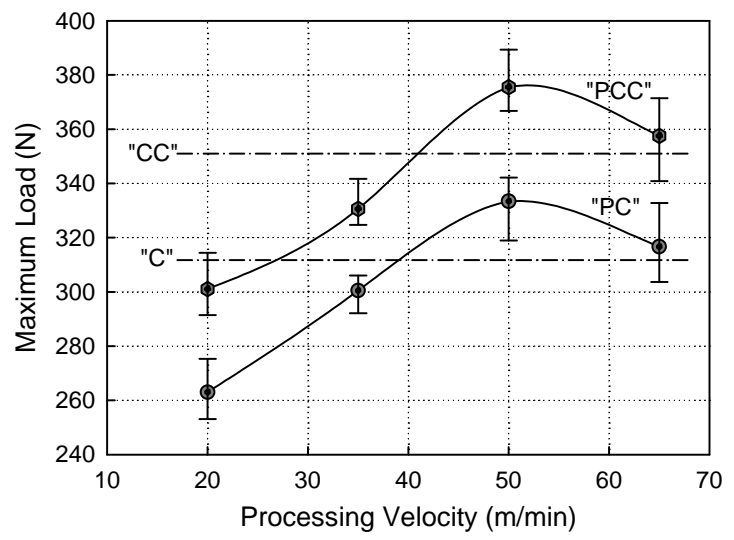

Fig. 3 Effects of processing velocity of flame plasma on the maximm load.

\section{3 접착실험 방법}

접착특성시험(KS M 6787)의 시험편 크기는 폭이 $25.4 \mathrm{~mm}$ 이고 길이는 $127 \mathrm{~mm}$, 두께는 $5.4 \mathrm{~mm}$ 이었고, 피착제에 부착된 고무를 $90^{\circ}$ 박리를 하였다. 실험에 사용된 시험기는 Shimadzu 사의 Autograph (Model AG-5000E)이며, 실온 $\left(22 \pm 2^{\circ} \mathrm{C}\right)$ 에서 시 험속도는 분당 $50 \mathrm{~mm}$, 시험기로부터 매 $0.04 \mathrm{~mm}$ 변위 당 하중 값을 얻는다. 실험의 시료는 시편 4 개 이상을 사용하였으며, 얻어진 결과는 이들을 산술평균 하였다.

\section{3. 실험결과 및 토의}

\section{1 화염 플라즈마 처리 조건의 영향}

첫째로 버너 포트의 이동속도 4가지 중 가장 접착 하중이 높 은 $50 \mathrm{~m} / \mathrm{min}$ 일 때, 화염 플라즈마 길이의 영향에 대한 실험 결 과를 Fig. 2에 나타냈다. "L" 값이 40 부근에서 최대하중이 가장

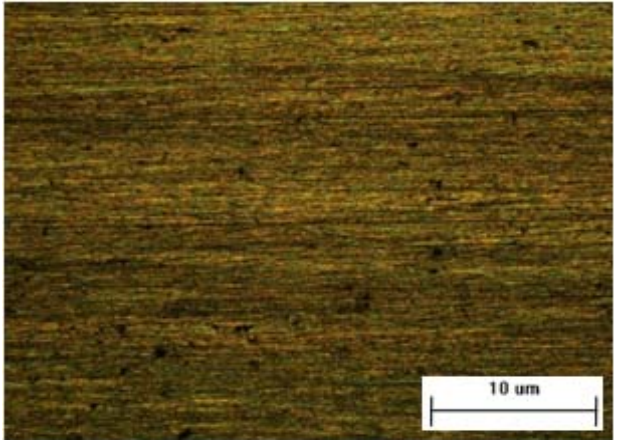

(a) untreated steel

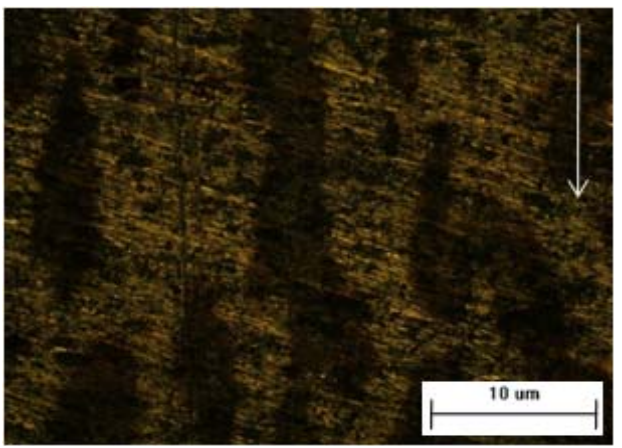

(b) $20 \mathrm{~m} / \mathrm{min}$

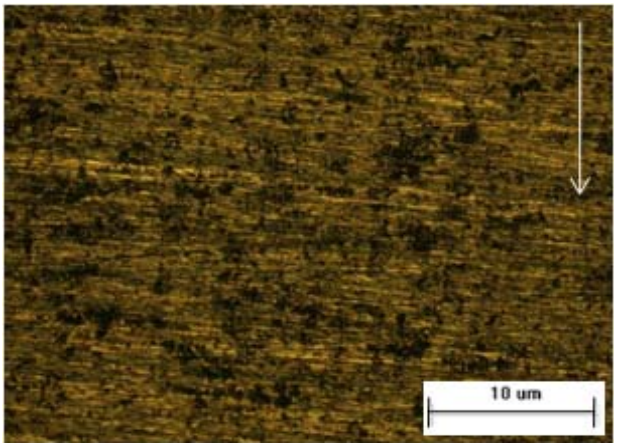

(c) $50 \mathrm{~m} / \mathrm{min}$

Fig. 4 Photographs of untreated steel plate(a) and steel plate surface(b, c) with flame plasma treatment.

높은 값을 보였으며, 버너 포트로 부터 거리가 더 멀어질수록 최대 하중이 감소하여 70 부근에서는 플라즈마 처리의 영향이 비교적 낮게 나타났다. 그러나 25부근에서도 낮은 값을 보였다. 25부근은 Fig. 1의 일차 영역(primary zone)에 가까운 곳으로 완 전연소가 되지 않고 플라즈마 영역 가운데 비교적 온도가 낮은 영역이다. 따라서 플라즈마 처리 효과가 높지 않은 것으로 보인 다. 이번 연구에 사용된 접착제(켐록 $\mathrm{AB}$ )는 강과 고무의 접착 등에 광범위하게 쓰이는 것으로, 화염 플라즈마 처리로 플라즈 마 처리 전보다 $7 \%$ 의 최대하중이 증가하였다. 


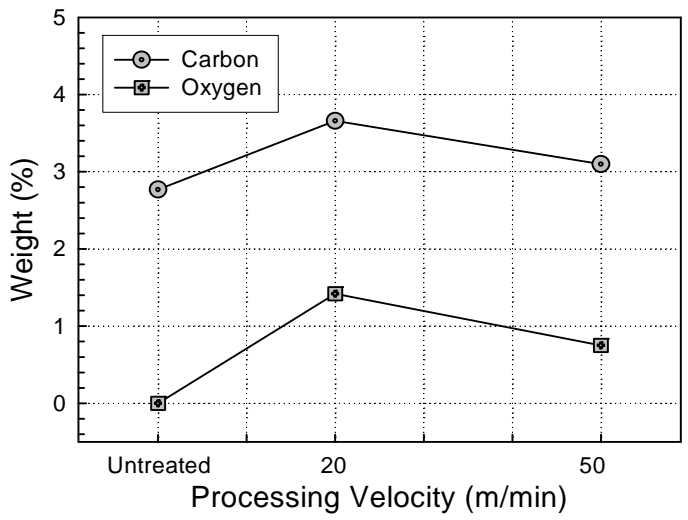

Fig. 5 Effects of processing velocity of the element content using EDS.

둘째로 화염 플라즈마 길이(“ $\mathrm{L”)} \mathrm{4가지} \mathrm{중} \mathrm{접착하중이} \mathrm{가}$ 장 높은 40 일 때, 버너 포트의 이동속도에 따른 실험결과를 Fig. 3에 나타냈다. 플라즈마 처리속도의 증가에 따라 최대하 중 값이 크게 증가하였고, $50 \mathrm{~m} / \mathrm{min}$ 에서 가장 높은 최대하중 값을 보였다. $65 \mathrm{~m} / \mathrm{min}$ 에서는 감소하였지만 접착제 처리상태 (“C”, “CC”)보다 높은 값을 보였다. 하지만 처리속도가 $50 \mathrm{~m} / \mathrm{min}$ 이하에서는 접착제 처리상태 보다도 오히려 낮은 값 을 보였다. 이는 화염 플라즈마의 고온 특성에 기인한다고 본 다. Fig. 1 의 2차 영역(secondary zone)은 완전연소에 의한 고온(약 $\left.1000^{\circ} \mathrm{C}\right)$ 영역으로 처리속도가 늦을 경우는 강 표면 에 열 영향이 크게 작용하는 것으로 판단된다. 따라서 처리속 도를 $50 \mathrm{~m} / \mathrm{min}$ 정도를 유지 하는 것이 유리할 것으로 보인다.

Fig. 4(a)는 플라즈마 처리 전 강 표면의 광학 현미경 $(\mathrm{LV}$ 150) 사진이고, (b)와 (c)는 각각 처리속도 $20 \mathrm{~m} / \mathrm{min}$ 와 $50 \mathrm{~m} / \mathrm{min}$ 으로 플라즈마 처리 후의 사진을 나타냈다. 비교적 저속으로 플라즈마 처리할 때는 반응기가 생성되더라도 고온 의 영향으로 피착제 표면의 온도가 갑자기 상승했다가 상온 으로 돌아오면서 표면에 산화반응이 일어나 변색되었음을 알 수 있다. 고온부식은 $600^{\circ} \mathrm{C}$ 이상의 고온에서 철의 표면으로 부터 산소의 침범에 의해 산화물로 변하는 것으로 자철 $\left(\mathrm{Fe}_{3} \mathrm{O}_{4}, \mathrm{FeO}\right)$ 이 형성되며, 이것이 냉각되면서 산소 등과 반 응하여 적철 $\left(\mathrm{Fe}_{2} \mathrm{O}_{3}\right)$ 이 생성된다. Fig. 4 에서 화살표( $\left.\downarrow\right)$ 는 화 염 플라즈마의 처리 방향을 나타낸 것으로, (b)의 경우 플라 즈마 처리 방향으로 산화가 심하게 발생하였음을 알 수 있다. 이러한 산화층이 고무와 강의 접착 반응을 방해하는 것으로 판단된다. 하지만 Fig. 4(c)에서와 같이 $50 \mathrm{~m} / \mathrm{min}$ 의 비교적 빠 른 속도에서는 표면 산화가 크게 발생하지 않고, 부서지기 쉬 운 적철의 전단계인 단단한 자철 단계라고 볼 수 있다. 이와 같이 강 표면에 화염 플라즈마 처리를 통한 표면의 산화가 발생하였음을 확인하였고, 이는 다른 형태의 대기압 플라즈마 를 이용한 연구[7,9] 예에서도 유사한 결과를 보였다.

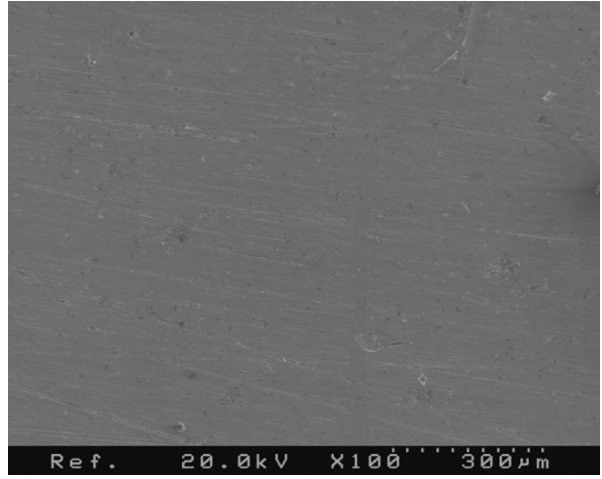

(a) untreated steel

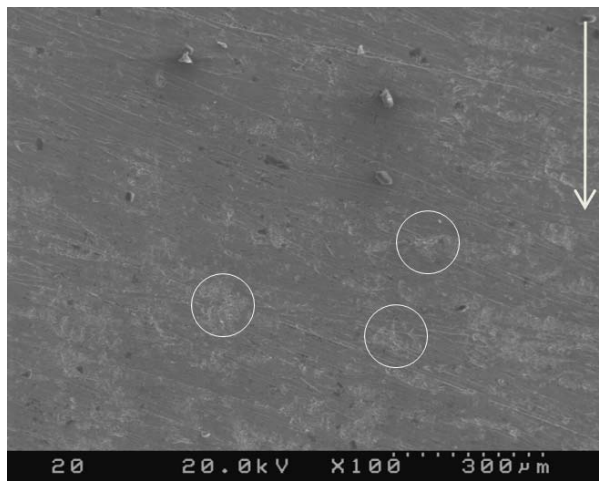

(b) $20 \mathrm{~m} / \mathrm{min}$

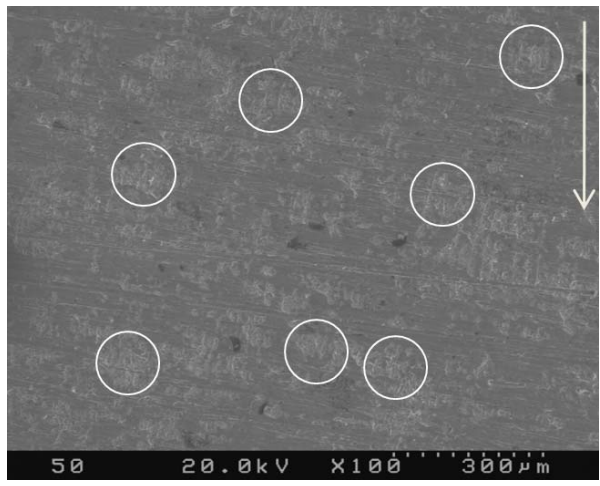

(c) $50 \mathrm{~m} / \mathrm{min}$

Fig. 6 SEM photographs of untreated steel plate and steel plate surface with flame plasma treatment.

화염 플라즈마 처리속도에 따른 철 표면의 산화 정도를 분 석하기 위해 주사전자현미경(Hitachi, S-4200)의 EDS (energy dispersive spectroscopy)장비를 이용하였다. Fig. 5는 처리속도 에 따른 탄소와 산소의 중량 비를 나타냈다. 처리속도가 늦은 $20 \mathrm{~m} / \mathrm{min}$ 인 경우가 $50 \mathrm{~m} / \mathrm{min}$ 인 경우에 비해 산소와 탄소 함유 량이 높게 나타나 산화가 크게 발생하였음을 알 수 있다. 


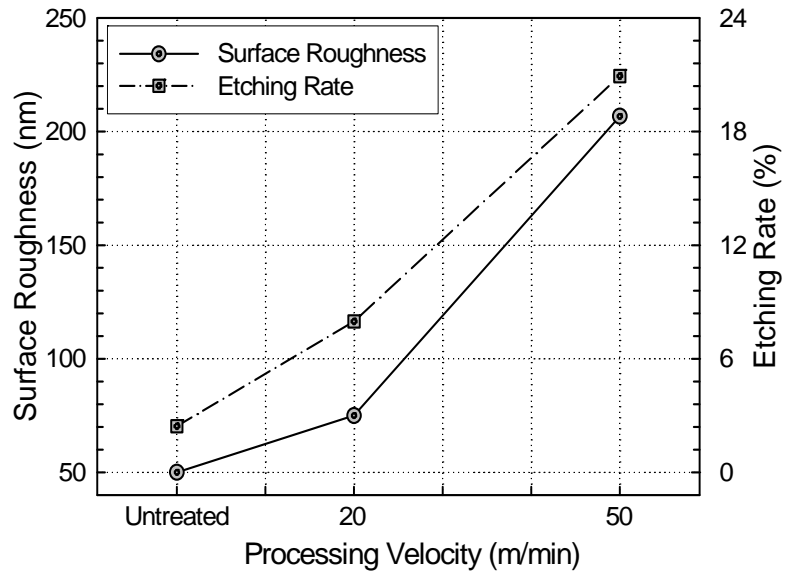

Fig. 7 Effects of processing velocity of the surface roughness and etching rate.

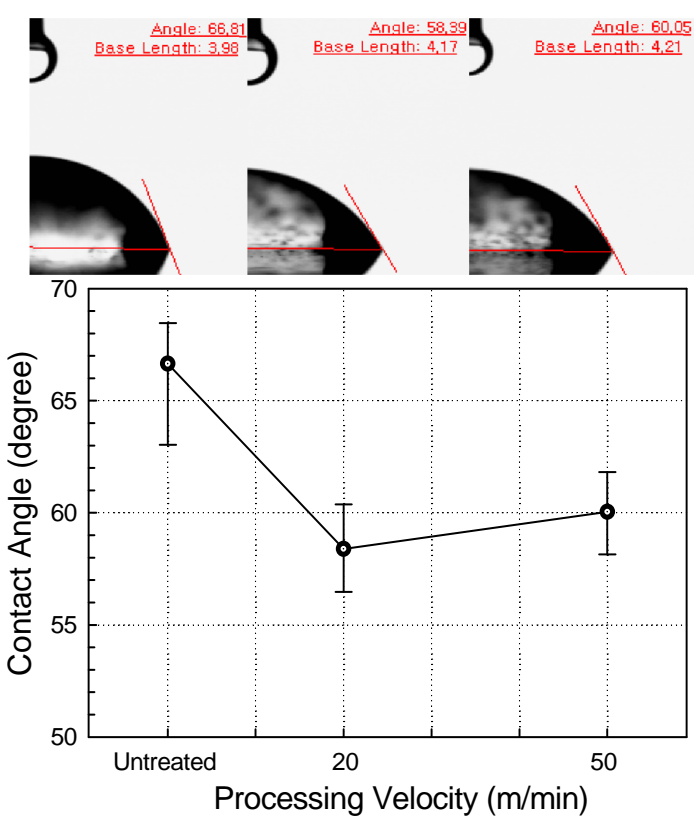

Fig. 8 Effects of processing velocity of the contact angle.

Fig. 6은 미처리 강과 플라즈마 처리 강의 처리속도에 따 른 SEM 사진이다. 플라즈마 처리 전후가 명확히 구분되고, 처리 방향 $(\downarrow)$ 으로 속도가 $50 \mathrm{~m} / \mathrm{min}$ 인 경우가 $20 \mathrm{~m} / \mathrm{min}$ 인 경 우에 비해 강 표면의 에칭된 면적이 더욱 넓음을 알 수 있 다. Fig. 7은 표면 거칠기(OptoTop®, 3D optical surface profile)와 에칭률을 플라즈마 처리속도에 따라 나타냈다.

에칭률은 그래픽 프로그램(paint.net)을 이용해 전체면적에 대한 에칭된 부분의 비율을 백분율로 나타낸 것이다. 플라즈 마를 처리하지 않은 상태 $(50 \mathrm{~nm}, 2.44 \%)$ 에 비해 처리 후가 비
교적 높은 값을 보였으며, 처리속도가 늦은 $20 \mathrm{~m} / \mathrm{min}$ 인 경우 $(75 \mathrm{~nm}, 7.97 \%)$ 가 $50 \mathrm{~m} / \mathrm{min}$ 인 경우 $(207 \mathrm{~nm}, 20.93 \%)$ 에 비해 오 히려 낮은 값을 보였다. 이는 비교적 빠른 속도 $(50 \mathrm{~m} / \mathrm{min})$ 로 처리하면 표면 거칠기와 에칭률이 상승하지만, 처리속도가 늦게 되면 고온의 영향이 지속되어 미세하게 형성되었던 거 칠기가 다시 무너지기 때문인 것으로 사료된다. 이[9] 등도 저온의 대기압 $\mathrm{Ar} / O_{2}$ 플라즈마 처리를 통해 실험적 오차 범 위지만 $92 \mathrm{~nm}$ 의 표면조도 변화가 있음을 보였다.

또한 플라즈마의 처리속도에 따른 표면의 영향을 분석하 기 위하여 접촉각을 측정하였다. Fig. 8은 화염 플라즈마에 의한 세정효과를 시험한 결과를 나타냈다. 표면 세정의 효과 적인 측정 방법은 물방울의 접촉각을 관찰하여 알 수 있다 [11-14]. 정접촉각 실험(CAM200-AutoD) 결과 플라즈마를 처 리하지 않은 상태 $\left(66.6^{\circ}\right)$ 에 비해 처리 후가 낮은 값을 보여 세정효과가 있음이 확인되었고, 이를 통한 젖음성 개선으로 접착 효과를 높일 수 있다. 처리속도가 늦은 $20 \mathrm{~m} / \mathrm{min}$ 인 경 우 $\left(58.4^{\circ}\right)$ 가 그만큼 표면 세정시간이 길어지기 때문에 $50 \mathrm{~m} / \mathrm{min}$ 인 경우 $\left(60.1^{\circ}\right)$ 에 비해 낮은 값을 보였다. 또한 이[9] 등도 $\mathrm{Ar} / O_{2}$ 플라즈마 처리 시간이 증가함에 따라 특정 시점 까지는 접촉각이 감소하지만, 산화물이 표면에 충분히 생성 된 후에는 접촉각이 다시 증가함을 보였다.

Fig. 9는 플라즈마 처리속도에 따른 접착시험 후 강의 표 면 사진을, Fig. 10 은 고무 잔류율과 최대하중 값을 나타냈 다. Fig. 9의 화살표 $(\rightarrow)$ 는 박리가 시작된 방향을 의미하고, 화염 플라즈마의 처리속도에 따라 피착제의 색이 다소 다르 게 나타났다. 또한 처리속도가 $50 \mathrm{~m} / \mathrm{min}$ 인 경우가 $20 \mathrm{~m} / \mathrm{min}$ 인 경우에 비해 피착제의 고무 잔류율과 최대하중이 높으며, 계 면 파괴보다는 고무층 파괴에 가까운 형태를 보였다.

\section{2 접착강도}

피착제와 고무의 접착강도 $\left(T_{a}\right)$ 는 하중-변위 곡선에서의 최대하중 $(F, \mathrm{kN})$ 값을 시편의 폭 $(b, \mathrm{~m})$ 으로 나누어 계산한다 [15].

$$
T_{a}=\frac{F}{b}
$$

최대하중 값은 앞 절에서 고찰한 바와 같이 최대값을 보 이는 조건 즉, 화염플라즈마 길이가 $40 \mathrm{~mm}$ 이고 버너 포트의 이동속도가 $50 \mathrm{~m} / \mathrm{min}$ 일 때의 값이다. Fig. 11 은 피착제와 고 무의 접착강도 값을 나타냈다. 화염 플라즈마 처리 후(“PC", “PCC”)가 처리 전(“C”, “CC”) 보다 약 $7.0 \%$ 정도 접착강도 가 증가하였고, 화염 플라즈마 처리 후 켐록의 중복 처리로 인해 접착만 도포한 경우 보다 약 $20.5 \%$ 의 접착강도가 증가 함을 알 수 있다. 


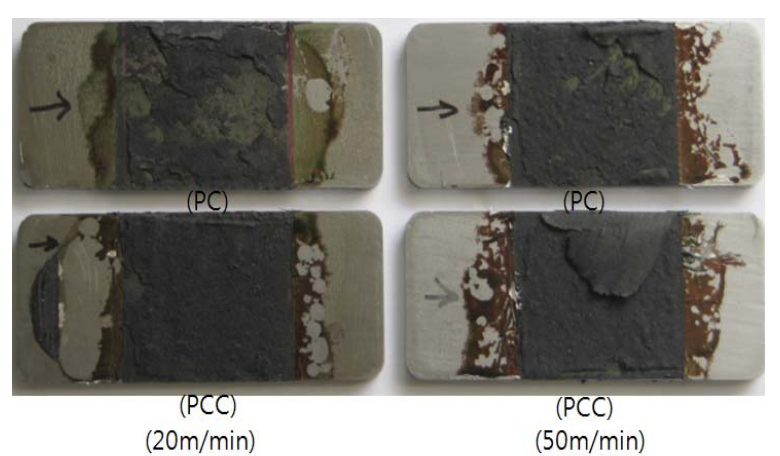

Fig. 9 Photographs of peeled steel surface.

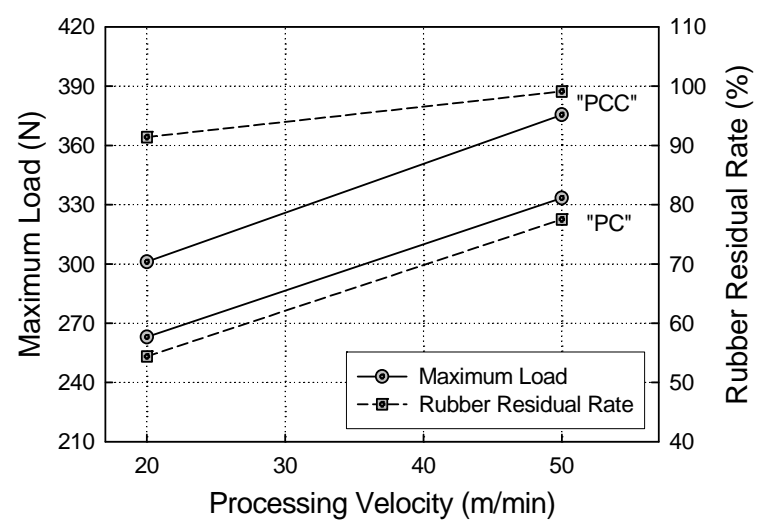

Fig. 10 Effects of processing velocity of the maximum load and nuber residual rate.

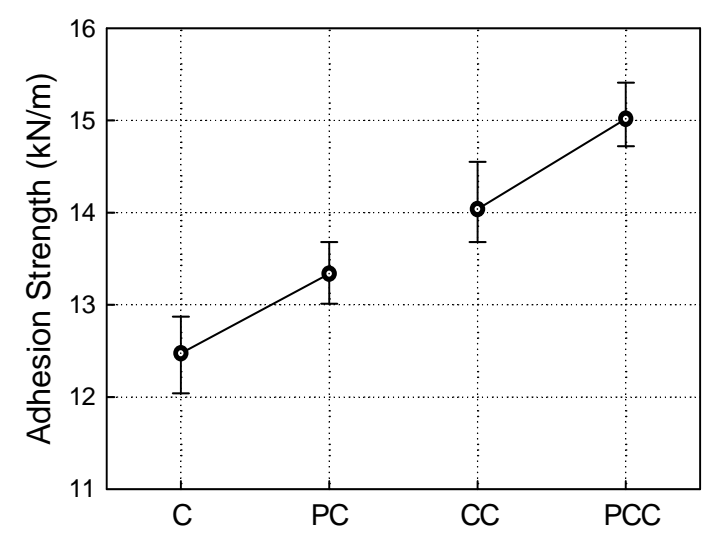

Fig. 11 Effects of flame plasma and bonding agent treatment of steel plate on the adhesion strength.

\section{4. 결 론}

강판의 대기압 화염 플라즈마 처리의 최적조건 설정 및
고무와의 접착 특성에 대한 실험적 연구에서 다음과 같은 결 론을 얻었다.

1) 화염 플라즈마를 이용한 강의 표면 처리에 있어서 처리 조건에 따라 표면 거칠기의 미세 제어 및 젖음성 개선으 로 표면 개질이 가능함을 확인하였다.

2) 버너 포트와 피착제 사이의 거리(화염 플라즈마 길이)는 $40 \mathrm{~mm}$ 부근에서 가장 높은 하중 값을 보였으며, 길이가 증가하거나 감소할수록 플라즈마 처리의 효과가 낮게 나 타났다.

3) 버너 포트의 이동 속도(화염 플라즈마 처리속도)는 $50 \mathrm{~m} / \mathrm{min}$ 에서 가장 높은 하중 값을 보였으며, $50 \mathrm{~m} / \mathrm{min}$ 이 하에서는 플라즈마의 고온 영향으로 접착제만 처리한 경 우 보다 오히려 낮은 값을 보였다.

4) 최적조건으로 플라즈마 처리 후 접착제(켐록 $\mathrm{AB}$ )를 중 복 도포한 강 피착제와 $\mathrm{NBR}$ 의 접착강도는 접착제만 1 회 도포한 경우보다 $20.5 \%$ 증가하였다.

5) 장치가 소형이고 처리속도가 빠르며 유기 용제 등을 사 용하지 않은 등의 장점이 있는 화염 플라즈마 장치를 이 용하여, 강과 고무 복합재료의 접착 특성 향상이 가능함 을 확인했다.

\section{후 기}

본 연구는 2009년도 한국과학재단 일반연구비(2009- 0076679) 에 의해 수행되었으며, 이에 감사드립니다.

\section{참고문헌}

1) Park S.J. and Kim J.S., "Modifications Produced by Electrochemical Treatment on Carbon Blacks: Microstructures and Mechanical Interfacial Properties,” Carbon, Vol. 39, 2001, p. 2011.

2) Kim J.S., Kim Y.K. and Lee K.H., "Effects of Atmospheric Plasma Treatment on the Interfacial Characteristics of Ethylene-Vinyl acetate/Polyurethane Composites,” J. Colloid Interface Sci., Vol. 271, 2004, pp. 187-191.

3) Kim Y.H. and Wool R.P., "A Theory of Healing at a Polymer-Polymer Interface,” Macromolecules, Vol. 16, 1983, p. 1115.

4) Jia W. and Chen X., "Effect of Polymer Filler Interaction on PTC Behaviors of LDPE/EPDM Blends Filled with Carbon Black,” J. Appl. Polym. Sci., Vol. 66, 1997, p. 7885.

5) Xizo G.Z., "Effects of Solvents on the Surface Properties 
of Oxygen Plasma-Treated PE and PP Films,” J. Adhesion Sci. Thechnol., Vol. 11, 1997, p. 655.

6) Kanazawa S., Kogoma M. and Okazaki S., "Stable Glow Plasma at Atmospheric Pressure," J. Phys, D: Apply. Phys., Vol. 21, 1998, p. 838.

7) Han M.H., Jegal J.P., Park K.W., Choi J.H., Baik H.K., Noh J.H., Song K.M. and Lim Y.S., "Surface Modification for Adhesion Enhancement of PET-Laminated Steel Using Atmospheric Pressure Plasma,” Surface \& Coatings Technology, Vol. 201, 2007, pp. 4948-4952.

8) Asad S.S., Tendero C., Dublanche-Tixier C., Tristant P., Boisse-Laporte C., Leroy O. and Leprince P., "Effect of Atmospheric Microwave Plasma Treatment on Organic Lubricant on a Metallic Surface," Surface \& Coatings Technology, Vol. 203, 2009, p. 1790.

9) 이찬주, 이상곤, 박근환, 김병민, “대기압 $\mathrm{Ar} / O_{2}$ 플라즈마 표면처리된 자동차용 냉연강판의 표면특성 및 접착특성 평가,” 대한기계학회논문집(A), Vol. 32, No. 4, 2008, pp. 354-361.

10) 이경엽, 양준호, 최낙삼, “플라즈마를 적용한 알루미늄의 표면처리가 알루미늄/CFRP 복합재의 접합강도에 미치는 영향,” 대한기계학회논문집(A), Vol. 25, No. 12, 2001, pp. 1981-1987.

11) 엄환섭, “대기압 플라즈마와 응용," 대한진공학회지, Vol. 15, No. 2, 2006, p. 119-123.

12) Yi C.H., Jeong C.H., Lee Y.H., Ko Y.W. and Yeom G.Y., "Oxide Surface Cleaning by an Atmospheric Pressure Plasma," Surface \& Coatings Technology, Vol. 177-178, 2004, pp. 711-715.

13) 신화섭, 김영수, 신상완, “표면 처리 방업에 따른 타이타늄의 미세 표면거칠기, 표면 젖음성, Fibronectin 흡착량에 미치는 영향," 대한치과보철학회지, Vol. 44, No. 4, 2006, pp. 443-453.

14) 심동현, 설수덕, “대기압 플라즈마를 이용한 고분자 소재의 표면개질,” Polymer(Korea), Vol. 32, No. 5, 2008, pp. 433-439.

15) KS M 6787:2009 가류고무의 접착 시험 방법. 